\title{
To Explore the Research and Development Competence and School-to-Work Transition for Hospitality Students
}

\author{
Wen-Hwa Ko ${ }^{1}$, Chieh-Ying Chen ${ }^{1}$ \\ ${ }^{1}$ Department of Restaurant, Hotel and Institutional Management, Fu-Jen University No.510, Zhongzheng Rd., \\ Xinzhuang Dist., New Taipei City, Taiwan \\ Correspondence: Wen-Hwa Ko, Department of Restaurant, Hotel and Institutional Management, Fu-Jen University, \\ No.510, Zhongzheng Rd., Xinzhuang Dist., New Taipei City, Taiwan.
}

Received: October 30, 2017

doi:10.11114/jets.v5i12.2808
Accepted: November 13, $2017 \quad$ Online Published: November 21, 2017

URL: https://doi.org/10.11114/jets.v5i12.2808

\begin{abstract}
This research focuses on the research and development competence and school-to-work transition on occupation selection for hospitality students with the use of social cognitive career theory. The positive attitude construct is the most identifiable for the research and development competences. For the school-to-work constructs, the most identifiable is the construct of learning and exploration, while the most identifiable among the self-efficacy constructs is the personal work attitude construct. The students' research and development competence and school-to-work transition to occupation selection are revealed. While the expectation result of professional competence is not significant; the others show significantly positive impact.
\end{abstract}

Keywords: career cognition theory, research and development competence, school-to-work transition, occupation selection

\section{Introduction}

Due to the nearly universal desire for higher education, there are currently numerous universities and graduate institutes in Taiwan. As a result, a university degree is no longer a job guarantee (Chang, Yang and Jiang, 2008). Whether looking for a job or position promotion opportunity, people have to strive for it in the midst of strong competition, and success depends on the cultivation of the individual's ability. Those who are successful under severe competition have actually cultivated their ability through education. Naturally, school education has become the critical link to one's future success since the goal of school education is helping the students develop their potential, and nurturing the elites demanded in industry (Wang and Shi, 2005).

Influenced by the current globalization of economic knowledge, the normally quiet labor market has undergone a severe change. Under such circumstances, cultivation of professional ability has become critically important. For the catering industry with its labor and technology intensity, human labor and talent are the two key factors that decide over $90 \%$ of success, demonstrating the importance of one's competitiveness. Huang (2005) stated that research and development, and innovation, have expanded the markets for the new product to satisfy consumers' needs. As a result, we know that research and development is indispensible for competitiveness, making a qualified research and development elite in catering industry one of the primary keys to success (Ko, 2015).

\section{Literature Review}

\subsection{Research and Development Competence for the Hospitality Industry}

Competence is the factor related to work performance; it includes attitude, cognition, personality traits, and so on. Ability is related to the factors which influence learning performance, and it is considered that intellectual assessment should be replaced by competence assessment (McClelland, 1973). Spencer \& Spencer (1993) define competence as one's potential basic traits, including professional knowledge, techniques, personal characteristics, motivation, and the like. It is the relative ability or skills developed by the worker in accordance with his/her personal characteristics in order to achieve specific goals or carry out work-related tasks. Under such definition, he proposed that there is a significant causal relationship between competence and work performance.

R\&D personnel refers to all those who participate in research development, including the research personnel directly 
participating in research, technical personnel assisting research and the supportive personnel. Ko (2015) said that creative ability can be strengthened through relevant professional and creativity-triggering trainings. When the R\&D personnel possess creative ability, creativity and competitiveness, a company's performance will be promoted. Abbey \& Discon (1983) also indicate that the R\&D personnel's competitive ability is the key factor determining whether the enterprise can grow in the future. As a result, the responsibilities of the R\&D personnel in catering-related industries include accumulating, creating and applying new knowledge. Though the literature mentioned above does not directly define what is related to the $\mathrm{R} \& \mathrm{D}$ competence in catering, there is some relevant literature. For example, Ko and $\mathrm{Li}$ (2010) conclude that instead of limiting the program design to aspects like knowledge and attitude, educational training programs for the Taiwanese Chinese food cooks in the future should include cooking knowledge, skills, attitude, and so on. In addition to cooking skills, cooks should be trained with peripheral capabilities, such as computer skills, language communication ability, innovative ability, and so on, all of which are helpful to raise the quality and competitiveness of the cooking profession. Ko and $\mathrm{Gu}$ (2014) also signify that in regard to new catering products, the R\&D personnel's competence can be explored from two aspects: R\&D professional ability and the personality characteristics of R\&D personnel. Among them, the professional R\&D abilities involve four dimensions: thinking reaction, leadership and talent, food awareness, and cooking devices. Similarly, the characteristics of R\&D personnel are reflected by challenges, positivity and responsibility, and persistence and anti-stress.

\subsection{School-To-Work Transition}

Will (1894) considers employment as the top goal of transition. He points out concretely that school is the important link to employment, and that the transition from school to work and then to adult life demands sound and complete preparations in school. Therefore, in his opinion, school has to provide effective teaching related to transition in order to cultivate the attitude, abilities and skills required for transition. Hendricks \&Wehman (2009) indicate that during the transition period from school to work, people will encounter a lot of challenges. Besides, some scholars hold that transition requires the cooperative relationship between institutions; as a result, transition can also be called occupational training or the important personal adaptive need that helps people to get accustomed to work/career (Johnson, McGrew, Bloomberg, Lin \& Bruininks, 1995).

As Brint (2006) explains, school must cultivate disciplined students with good behavior and principles. To realize these goals, schools must actively help students to adjust their behaviors, and assist them in becoming socialized in the workplace. Besides, it is also the school's responsibilities to instruct the students to collect useful data and develop correct concepts; these highlight the necessity for planning the social skill program for undergraduates to become familiar with the relevant points. Huang \& Ma (2011) express that the expertise cultivated in school, the type of school, and the major subjects that a graduate has learned in university have significant effects on job-seeking and working dynamics. According to the related literature, graduates' confidence will be raised if they can find a job related to their major. However, even if they fail to find such jobs, enlarging the potential employment space may be another solution (Blanco, 2011; Lin, 2011).

\subsection{School-To-Work Transition's Influence on Occupation Selection}

If higher education can actually provide career guidance, embrace teaching responsibilities, and succeed in carrying out the goals of delivering professional teaching-related knowledge and skills in class, and remaining aware of the career maturity of the students, the career development situation will be well controlled. Together with the guiding measures in school, it will help if the graduates conduct the self career exploration and career decisions after graduation and before entering the workplace (Chen, 2005). In this regard, Gordon and Habley (2000) hold that juniors in university must ensure their own expertise and cultivate the required fundamental skills and ability to search for career-related information. That is to say, in the process of moving towards mastering professionalism and realizing the promising future, students have to clarify and integrate what they learned; student satisfaction with their learning outcomes in school is the key to achieving their goals; thus, in many universities, evaluations are conducted for work exploration from the freshman year to guide their work career path in advance (Chen, 2005; Pryor \& Bright, 2006; Pryor, Amundson \& Bright, 2008). In Savickas' (1999) perspective, career consultation can raise the undergraduates' self-consciousness, goals, confidence, planning skills and positive adaption to career requirements. As for other scholars, proper career preparations can successfully foster the adaptive ability in transitioning from school to work since better preparations can help an individual succeed in looking for and finding employment opportunities as well as improving the results of their work/ careers (Creed \& Hughes, 2013; Hirschi, Niles \& Akos, 2011). Therefore, we can generalize that good occupational adaptation can raise the possibility of finding a suitable job, achieving success in position promotion, and even obtaining good general welfare (Hartung \& Taber, 2008; Hirschi, 2010).

\subsection{Occupation Selection Factors}

Social Cognitive Career Theory (SCCT), proposed by Lent, Brown and Hackett (1994), emphasizes self-efficacy, 
outcome expectation and goals selection. Besides, it takes into consideration the individual student and the contextual factors on the behavior of selection, and attempts to set up a processional theory for school-to-occupation selection of jobs. Furthermore, it indicates the students' learning experiences in certain aspects at an early stage, their learning achievements and outcomes will generate a definite interest in the particular field, and therefore gradually clarify what they will subsequently engage in. Consequently, this theory is very useful when applied to exploration and the explanation of how the related aspects of certain disciplines affect one's occupation selection motivation ( $\mathrm{Yu}, \mathrm{Chao}$ and Chen, 2010).

According to Lent, Hackett \& Brown (1994), self-efficacy is the commitment regarding an individual's ability to carry out a task, with the focus on one's ability. The outcome expectation means that, after the individual exhibits specific behaviors, his or her viewpoint will be affected by the results following that behavior. The focus lies in the psychology related to the personal concept of value. Selection of goals refers to choosing or insisting on specific action that can guide the individual to subsequently engage in more activities. Rothwell, Jewell \& Hardie (2009) also point out that the abilities influencing the employment of university students after graduation are related to the students' self-confidence, what they learned in club activities, their in-school performance and the reputation of the university. In fact, while they are on campus, they cannot ensure the direction of their future occupation selection. This condition is further worsened by the vague connection between their department and the external workplace, which produces considerably impedance in occupation selection (Swanson \& Tokar, 1991).

Consequently, since our research requires eliciting and replacing concepts like professional competence and school-to-work transition with similar ones as the framework, we adopt SCCT as the foundation, and the research framework of the SCCT model diagram as the prototype, together with the learning experience (source of self-efficacy and outcome expectation) proposed by Lent, Hackett \& Brown (1999). In accordance with the research motivation and purpose, in collaboration with a relevant literature discussion, we proposed the research hypothesis and framework based on SCCT, and replaced the original learning experiences (the source of self-efficacy and outcome expectation) in the theory with similar concepts like professional competence and school-to-work transition. The research framework in this study is shown as Figure 1.

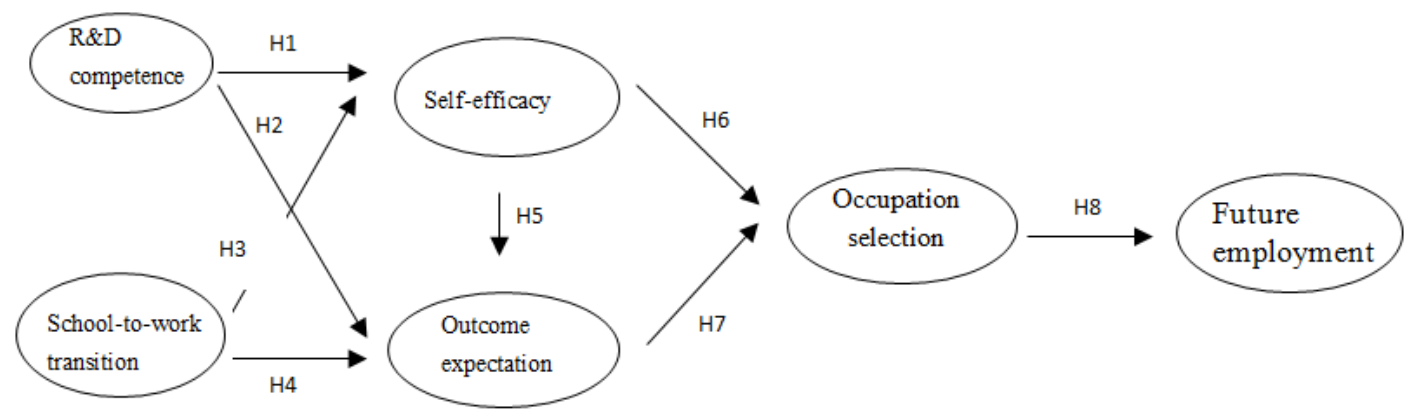

Figure 1. The research framework

In view of the above literature, the following hypothesizes are presented:

H1: R\& D competence is positively related to self-efficacy.

$\mathrm{H} 2$ : R\& D competence is positively related to outcome.

H3: School-to-work transition is positively related to self-efficacy.

H4: School-to-work transition is positively related to outcome expectation.

H5: Self-efficacy is positively related to outcome expectation.

H6: Self-efficacy is positively related to occupation selection.

H7: Outcome expectation is positively related to occupation selection.

H8: Occupation selection is positively related to future employment.

\section{Research Methodology}

\subsection{The Sample and Data Collection}

The subjects in this research are undergraduates in the colleges and universities in Taiwan, and the research range is a sampling investigation of the hospitality- and catering-related departments for further discussion. By means of convenience and purposive sampling, and via telephone and e-mails, we inquired regarding the intention of the students 
in hospitality- and catering-related departments and sought the teachers' assistance in mailing the questionnaires with stamped, addressed envelopes. We received 100 returned questionnaires in seeking to proceed with item analysis and factor analysis for extraction of the final questionnaires. Finally, a total of 500 questionnaires were issued, with 462 effective ones returned, so the effective questionnaire's return rate was $92.4 \%$.

\section{Measures}

The questionnaires we used can be categorized into seven parts: R\&D competence, school-to-work transition scale, self-efficacy, future work expectation, R\&D occupation selection and future career development. The items in all scales were rated using a five-point Likert-type scale, with answers ranging from 1 (strongly disagree) to 5 (strongly agree). The last part is the personal information questionnaire.

This study used the following scales:

R\&D Competence: This scale refers to the scale of R\&D personnel for new catering products; it was constructed by Ko (2015), and the main constructs taken into consideration include: product-related skills, positive attitudes, management ability, innovation and change, and the personality stability. The Cronbach's $\alpha$ obtained for the five constructs are 0.898 , $0.798,0.819,0.828$ and 0.797 , respectively, showing good reliability.

School-to-work Transition Scale: This scale refers to the transition service scale constructed by Stringer, Kerpelman \& Skorikov (2011), and was organized with the transition service degree question analysis as the foundation. The scale is divided into a learning \& exploration construct, and career guidance construct. The overall Cronbach $\alpha$ value is 0.899 . The Cronbach $\alpha$ value of each construct is 0.868 for "learning \& exploration", and 0.789 for "career guidance construct".

Scale of self-efficacy, outcome expectation and occupation selection: This scale refers to Blanco's (2011) SCCT Scale, as the foundation in creating the Self-awareness Evaluation Scale for the hospitality R\&D personnel. The scale is divided into the self's work performance construct and the self's work content construct. The overall Cronbach $\alpha$ value is 0.941 . The Cronbach $\alpha$ value of each construct is 0.926 for "self's work performance", and 0.891 for "the self's work attitude". The overall Cronbach $\alpha$ value for the scales of outcome expectation is 0.932 . The overall Cronbach $\alpha$ value for the scales of occupation selection is 0.926 .

The scale of future career development: This questionnaire refers to the Employment Development Scale of Ko (2012) as the foundation, and we modified it to present the responders' degree of agreement regarding future employment development. The Cronbach $\alpha$ value is 0.928 . All of the above scores are at acceptable levels.

The basic personal information included gender, grade, learning group and department.

\section{Data Analysis}

The collected data were analyzed using Statistical Package for Social Sciences (SPSS), version 18.0. We analyzed according to our research purpose and research hypotheses; the quantitative statistic methods for analysis include: item analysis, descriptive statistic analysis, factor analysis, reliability analysis, validity analysis and structural equation analysis.

The two-step procedure consisting of the measurement model analysis and structural model analysis was used for structure equation modeling (SEM) (Anderson and Gerbing, 1988). To execute the SEM analysis, we used Maximum Likelihood (ML) and estimated the parameters, since LISREL assumes multivariate normality of data (Version 8.54). We examined the reliability and discriminant validity among the variables in the first step of the measurement model analysis. We assessed the hypothesized theoretical model and estimated the parameters for the subsequent structural model analysis. The overall fit index of the model is as follows: chi-squared statistic $\left(\chi^{2}\right)$, chi-squared statistic adjusted by the degrees of freedom $\left(\chi^{2} / \mathrm{df}\right)$, root mean square error of approximation (RMSEA), the goodness-of-fit index (GFI), normed-fit index (NFI) and comparative fit index (CFI); these were all evaluated. The value of the $\chi^{2} / \mathrm{df}$ ratio should be less than 5; less than 3 is better (Joreskog and Sorbom, 1993). Acceptable model fits are indicated by a GFI above 0.8 and CFI values above 0.90 . An RMSEA value at or below 0.08 shows good fit, while 0.08 to 0.1 demonstrates mediocre fit (Bagozzi and Yi, 1988; Kline, 2005).

\section{Results and Discussion}

\subsection{Participants' Demographic Information}

Of the 462 valid questionnaires, female participants accounted for $69 \%$ of the total, while males accounted for the remaining $31 \%$ (Table 1). Respondents' grade was predominantly seniors $(57.1 \%)$. Approximately $50.6 \%$ of the respondents had studied in general universities and $49.4 \%$ at technology universities. Finally, regarding department, there were 300 students were in a hospitality management department, accounting for 64.9\%; and 129 in a food and beverage department, accounting for $27.9 \%$, with 33 in a culinary art department, accounting for $7.1 \%$. 
Table 1. Participants' demographic information

\begin{tabular}{llll}
\hline Background Variable & Category & Number & Percentage (\%) \\
\hline \multirow{2}{*}{ Gender } & Male & 143 & 31.0 \\
& Female & 319 & 69.0 \\
\hline \multirow{3}{*}{ Grade } & Sophomore & 45 & 9.7 \\
& Junior & 153 & 33.1 \\
\multirow{2}{*}{ Learning Group } & Senior & 264 & 57.1 \\
\hline \multirow{3}{*}{ Department } & General universities & 234 & 50.6 \\
& Technology universities & 228 & 49.4 \\
\hline & Hospitality management department & 300 & 64.9 \\
& Food and beverage department & 129 & 27.9 \\
\hline
\end{tabular}

Note: $\mathrm{n}=462$

\subsection{Measurement Model and the Means of the Main Variable Scales}

The measurement model was analyzed using CFA to confirm the research constructs. CFA matches the traditional scale development process, providing an alternative measure of the internal and external consistency of the scale items (Sethi and King, 1994). The CFA showed the measurement model used in this study demonstrated a good fit, $\chi^{2} / \mathrm{df}=2.337$, RMSEA $=0.054, \mathrm{GFI}=0.879, \mathrm{NFI}=0.915$ and $\mathrm{CFI}=0.949$. As shown in Table 1 , Cronbach's $\alpha$ of each measurement scale was higher than 0.819. Composite reliability of each measurement scales ranged from 0.810 to 0.932 , demonstrating internal consistency between corresponding constructs. The average variance extracted (AVE) of all constructs, 0.5, surpassed the minimum value (Fornell and Lacker, 1981). Discriminant and convergent validity were ensured.

From Table 2, it is learned that the full scale mean of the R\&D competence is 3.95. Among the constructs, "positive attitude" is the highest mean, followed by "personality stability" and "innovation \& change". The mean of the full scale of school-to-work transition is 3.78. The mean of "learning and exploration" is the highest, followed by "career guidance". The full scale of self efficacy is 3.80. Among these, the mean of "self work content" is the highest, followed by self work attitude. The mean of the full scale of outcome expectation is 3.83. As the research results show, among the outcome expectation, the most influential to the students is the construct of engaging in hospitality R\&D work. As the students evaluated, "engaging in hospitality R\&D-related work creates a positive image, and makes others recognize my professional ability" is closest to their own condition. Occupation selection showed that the students' self-evaluation results demonstrate their willingness to engage in the R\&D work. That is, the hospitality students possess energy for the hospitality-related R\&D work, and they may take it into consideration in seeking a job. They regard the statement: "R\&D skills will as my profession ability at hospitality field" as the item closest to their own condition, followed by "I will set the catering R\&D competence as a useful professional tool in my career" and "I will take part in more courses related to catering R\&D work". The scale of future employment is 3.67. In each item, "under the premise of continuing my R\&D work, I believe there is still a big space for me to improve" is the item closest to the students' condition as they self-apprised.

The relationships among the constructs are shown in Table 3. Based on the above results, the research found that positive correlative relationships among competence, school-to-work transition, self-efficacy, outcome expectation and future employment

In order to confirm the reasonability of the hypotheses in this study, we conducted the following analysis for the questions in the scale to test the structural equation model. This research adopted indicators like GFI, AGFI, RMSEA, SRMR, NFI, CFI, TLI and $\chi 2 / \mathrm{df}$ for the adaptability tests. Figure 2 shows the results: all indicators passed the standard, and the model can illustrate the influence on each construct.

The data on the maximum likelihood estimation show good fit, $\chi^{2}=956.394, \chi^{2} / \mathrm{df}=2.415$, RMSEA $=0.055$, GFI $=0.874$, $\mathrm{NFI}=0.911$ and $\mathrm{CFI}=0.946$. As indicated by these fit indexes, the model has good fit, thus supporting the testing validity of the hypothesized paths. The parameter estimates of the structural model demonstrate the direct effects on each construct. Thus, the coefficient at a certain alpha level shows significant relationships between the latent constructs (Figure 2). 
Table 2. Properties of the measurement model

\begin{tabular}{|c|c|c|c|c|c|}
\hline Constructs & $\begin{array}{l}\text { Std. factor } \\
\text { loadings }\end{array}$ & $\begin{array}{l}\text { Cronbach's } \\
\alpha\end{array}$ & $\mathrm{CR}$ & AVE & Means \\
\hline \multicolumn{6}{|l|}{ R\&D competence ${ }^{q}$} \\
\hline A1 Product skills & 0.61 & \multirow{5}{*}{0.876} & \multirow{5}{*}{0.884} & \multirow{5}{*}{0.606} & 3.74 \\
\hline A2 Positive attitudes & 0.82 & & & & 4.18 \\
\hline A3 Management ability & 0.79 & & & & .80 \\
\hline A4 Innovation \& change & 0.84 & & & & 4.01 \\
\hline A5 Personality stability & 0.81 & & & & 4.04 \\
\hline School-to-work transition ${ }^{b}$ & & \multirow{3}{*}{0.831} & \multirow{3}{*}{0.818} & \multirow{3}{*}{0.693} & 3.78 \\
\hline B1 Learning and exploration & 0.92 & & & & 3.79 \\
\hline B2 Career guidance & 0.77 & & & & 3.77 \\
\hline Self- efficacy ${ }^{c}$ & & \multirow{3}{*}{0.819} & \multirow{3}{*}{0.810} & \multirow{3}{*}{0.681} & 3.80 \\
\hline C1 Self work performance & 0.85 & & & & 3.62 \\
\hline C2 Self work attitude & 0.82 & & & & 3.99 \\
\hline Outcome expectation(R\& D work...) & & \multirow{9}{*}{0.931} & \multirow{9}{*}{0.932} & \multirow{9}{*}{0.631} & 3.83 \\
\hline $\mathrm{D} 1 \ldots$...is very useful for my work career. & 0.80 & & & & 3.73 \\
\hline $\begin{array}{l}\text { D2 ... allows me to take part in activities related to my occupational } \\
\text { interests. }\end{array}$ & 0.79 & & & & 3.72 \\
\hline D3 ... enables me to get even more familiar with my knowledge area. & 0.82 & & & & 3.88 \\
\hline D4 ... helps me enhance my professional work. & 0.81 & & & & 3.89 \\
\hline D5 ... helps a lot in fostering my work career. & 0.81 & & & & 3.77 \\
\hline D6 ... helps a lot in my future professional abilities. & 0.80 & & & & 3.83 \\
\hline D7 ...helps me feel competent in work. & 0.81 & & & & 3.82 \\
\hline $\begin{array}{l}\text { D8...creates a positive image, and makes others recognize my } \\
\text { professional ability. }\end{array}$ & 0.71 & & & & 3.96 \\
\hline Occupation selection & & \multirow{7}{*}{0.923} & \multirow{7}{*}{$24^{0.9}$} & \multirow{7}{*}{0.670} & 3.70 \\
\hline E1 I will participate in more R\&D-related activities & 0.80 & & & & 3.67 \\
\hline E2 I will choose a catering R\&D-related major and work in the future & 0.83 & & & & 3.64 \\
\hline $\begin{array}{l}\text { E3 I will set catering R\&D competence as a useful professional tool in } \\
\text { my career }\end{array}$ & 0.83 & & & & 3.76 \\
\hline E4 R\&D skills will as my profession ability at hospitality field. & 0.83 & & & & 3.79 \\
\hline E5 I will engage in R\&D work. & 0.78 & & & & 3.63 \\
\hline E6 I will take part in more courses related to R\&D work. & 0.84 & & & & 3.73 \\
\hline Future employment & & \multirow{8}{*}{0.913} & \multirow{8}{*}{0.914} & \multirow{8}{*}{0.603} & 3.67 \\
\hline $\begin{array}{l}\text { F1 Judging from my current situation, I believe that I am very suitable for } \\
\text { R\&D work. }\end{array}$ & 0.78 & & & & 3.40 \\
\hline $\begin{array}{l}\text { F2 I believe that becoming an } R \& D \text { professional employee can bring me } \\
\text { a remarkable sense of achievement. }\end{array}$ & 0.79 & & & & 3.60 \\
\hline F3 Being an R\&D professional is of great benefit to my personal image. & 0.77 & & & & 3.65 \\
\hline F4 I feel satisfied with fulfilling my career goals step by step. & 0.79 & & & & 3.66 \\
\hline $\begin{array}{l}\text { F5 I am confident of success in R\&D work and getting promoted to even } \\
\text { more important job positions. }\end{array}$ & 0.82 & & & & 3.66 \\
\hline $\begin{array}{l}\text { F6 I am confident about enriching my knowledge and skills to adapt to } \\
\text { any possible future changes. }\end{array}$ & 0.77 & & & & 3.83 \\
\hline $\begin{array}{l}\text { F7 Under the premise of continuing my R\&D work, I believe there is a } \\
\text { large room for improving myself. }\end{array}$ & 0.71 & & & & 3.92 \\
\hline
\end{tabular}
Note:

a. Twenty-four measurement items of R \& D competence load onto five factors.

b. Twelve measurement items of school to work translate load onto two factors

c. Sixteen measurement items of self- efficacy load onto two factors 
Table 3. The correlation analysis of each variable

\begin{tabular}{|c|c|c|c|c|c|c|c|c|}
\hline Variable & Mean & S.D. & $\begin{array}{l}\text { The R\&D } \\
\text { competence }\end{array}$ & $\begin{array}{l}\text { School-to-work } \\
\text { transition }\end{array}$ & Self-efficacy & $\begin{array}{l}\text { Outcome } \\
\text { expectation }\end{array}$ & $\begin{array}{l}\text { Occupation } \\
\text { Selection }\end{array}$ & $\begin{array}{l}\text { Future } \\
\text { employment }\end{array}$ \\
\hline $\begin{array}{l}\text { The R\&D } \\
\text { competence }\end{array}$ & 3.95 & .495 & 1 & & & & & \\
\hline $\begin{array}{l}\text { School-to-work } \\
\text { transition }\end{array}$ & 3.78 & .567 & $.564 * * *$ & 1 & & & & \\
\hline Self-efficacy & 3.80 & .547 & $.650 * * *$ & $.625^{* * *}$ & 1 & & & \\
\hline $\begin{array}{l}\text { Outcome } \\
\text { expectation }\end{array}$ & 3.83 & .645 & $.534 * * *$ & $.594 * * *$ & $.714 * * *$ & 1 & & \\
\hline $\begin{array}{l}\text { Occupation } \\
\text { selection }\end{array}$ & 3.70 & .714 & $.453 * * *$ & $.528 * * *$ & $.680 * * *$ & $.720 * * *$ & 1 & . \\
\hline $\begin{array}{l}\text { Future } \\
\text { employment }\end{array}$ & 3.67 & .678 & $.469 * * *$ & $.544 * * *$ & $.683 * * *$ & $.718 * * *$ & $.780 * * *$ & 1 \\
\hline
\end{tabular}

Note:.n=462;*** $\mathrm{p}<0.01$

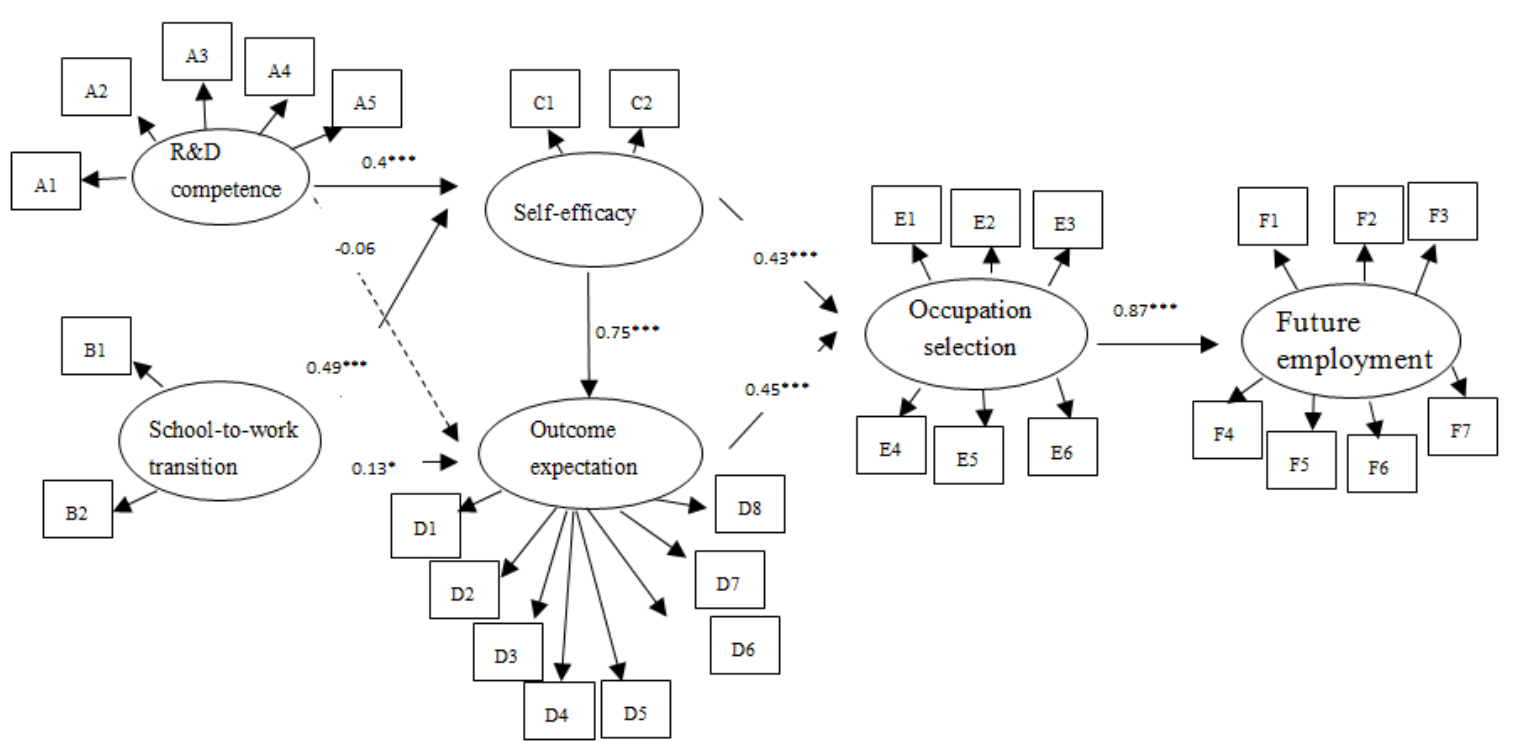

Figure 2. The whole structural model's path diagram

In order to confirm the significance of each construct's result, the path data in Fig. 2 were organized as the following table to inspect the significance degree of each construct's effect, which is divided into direct effect, indirect effect and total effect. According to Table 4, R\&D competence has a direct effect on self-efficacy, supporting H1. However, it does not have a significant direct effect on outcome expectation, although the total effect is significant. It shows that in R\&D competence, the item of outcome expectation does not support H2 in our research. Meanwhile, school-to-work transition to self- efficacy and school-to-work to outcome expectation are remarkably supportive of H3 and H4 in this research, and self-efficacy has a direct effect on outcome expectation, supporting H5. On the other hand, self-efficacy and outcome expectation show their significant effect on occupation selection, and support H6 and H7. Lastly, the effect of occupation selection on future employment is also significant and supports H8 in our research. 
Table 4. Direct effect, indirect effect and total effect for the constructs

\begin{tabular}{|c|c|c|c|c|}
\hline & Self- efficacy & $\begin{array}{l}\text { Outcome } \\
\text { expectation }\end{array}$ & $\begin{array}{l}\text { Occupation } \\
\text { selection }\end{array}$ & $\begin{array}{l}\text { Future } \\
\text { employment }\end{array}$ \\
\hline \multicolumn{5}{|c|}{$\mathrm{R} \& \mathrm{D}$ competence } \\
\hline Direct effect & $0.40^{* * *}$ & -0.06 & - & - \\
\hline Indirect effect & - & $0.30 * * *$ & $0.28 * * *$ & $0.24 * * *$ \\
\hline Total effect & $0.40^{* * *}$ & $0.25^{* * *}$ & $0.28^{* * *}$ & $0.24 * * *$ \\
\hline \multicolumn{5}{|c|}{$\begin{array}{l}\text { School-to-work } \\
\text { transition }\end{array}$} \\
\hline Direct effect & $0.49^{* * *}$ & $0.13 *$ & - & \\
\hline Indirect effect & - & $0.37 * * *$ & $0.43^{* * *}$ & $0.38^{* * *}$ \\
\hline Total effect & $0.49^{* * *}$ & $0.50 * * *$ & $0.43^{* * *}$ & $0.38 * * *$ \\
\hline \multicolumn{5}{|l|}{ Self- efficacy } \\
\hline Direct effect & & $0.75^{* * *}$ & $0.43 * * *$ & - \\
\hline Indirect effect & & - & $0.34 * * *$ & $0.66^{* * *}$ \\
\hline Total effect & & $0.75 * * *$ & $0.76^{* * *}$ & $0.66^{* * *}$ \\
\hline \multicolumn{5}{|l|}{$\begin{array}{l}\text { Outcome } \\
\text { expectation }\end{array}$} \\
\hline Direct effect & & & $0.45^{* * *}$ & - \\
\hline Indirect effect & & & - & $0.39^{* * *}$ \\
\hline Total effect & & & $0.45^{* * *}$ & $0.39 * * *$ \\
\hline \multicolumn{5}{|l|}{$\begin{array}{l}\text { Occupation } \\
\text { selection }\end{array}$} \\
\hline Direct effect & & & & $0.87^{* * *}$ \\
\hline Indirect effect & & & & - \\
\hline Total effect & & & & $0.87 * * *$ \\
\hline
\end{tabular}

*** $\mathrm{p}<0.001 ; * \mathrm{P}<0.05$

According to the analysis results, R\&D competence has a significantly positive effect. Accordingly, as the level of the students' catering R\&D competence is enhanced, their perceived self-efficacy will increase as well. Contrarily, if they do not possess the professional competence, their self-efficacy, sense of identity and confidence will decrease. Koivisto, Vinokur \& Vuori (2011) state that insufficient work development, inadequate working ability and poor disciplinary capability all limit students' future career choices, leading to stagnation of career development. Such argument complies with our proposal in this research, suggesting that when the students are equipped with sound competence, and when their school can provide complete transition service, the students will be more confident regarding their future occupation selection, and will perceive their self-efficacy. The literature mentioned previously indicated that several scholars integrated catering R\&D-related competence such as creative thinking math and creative cooking teaching in the courses, which all generated positive effects in respect to improving students' professional skills and creative thinking ability, and triggered students' learning interest and motivation to enhance their self-efficacy. In the same way, such results correspond with the results in our study. In addition, based on the analytical results, it is observed that significant correlation exists between school-to-work transition and self-efficacy. In this case, when the school-to-work transition courses are done well, the students will approve their self-efficacy to a larger extent; otherwise, their sense of self-efficacy will deteriorate. Scholarios et al. (2008) also point out that the catering R\&D competence must be accumulated through ceaseless learning. The graduates must develop their skills horizontally and extensively in order to adapt to new work requirements, and further cultivate a good attitude towards work.

The effect of R\&D competence on outcome expectation is not significant, which does not support H2 in our research. Besides, school-to-work transition has a significant effect on outcome expectation, implying that the extent of students' expectation concerning certain work increases the degree of the school-to-work transition service's completeness. Saks \& Ashforth (2002) propose that undergraduates should learn and explore extensively, and understand knowledge in 
different areas and levels in order to correspond to the diversified social environment in the future. Baer, Davusi, Flexer, Queen and Meindl (2011) claim that lack of career experiences, such as social work experiences, may cause failure of transition and incomplete transition service, so that the graduates' career development may not be ideal.

From the results, self-efficacy has a significantly positive effect on outcome expectation. In this regard, the higher the self-efficacy the students have, the more confident they will be regarding positive future outcome expectations. Contrarily, their outcome expectation will be negative if the students hold pessimistic attitudes toward self-efficacy. Alpern (2000) and Berger \& Malaney (2001) further point out, when the students actively seek information from relevant parties in school, their behaviors, experiences and satisfaction in the process of transition will have predictive power as to whether they can complete their education. Gordon and Habley (2000) show that the third year in the university is the stage when students must identify their expertise, set up their foundation, learning ability and skills. In this way, they may acquire career-related information, cultivate their expertise, and enhance their future possibilities. That is, in this stage, the students must clarify and integrate their schoolwork plan and career goals. In addition, whether the students are satisfied with their learning results may be the key to successfully achieving their goals. The above studies exhibit a similar viewpoint in this regard.

According to the analysis results, self-efficacy and outcome expectation has a significantly positive influence on occupation selection. If the students have higher self-efficacy, their energy in selecting a job will be stronger as well. In other words, they will have a positive image for certain jobs, and be more dynamic in selecting the job they desire. According to the abovementioned literature, proper working preparations can raise the adaptability in school-to-work transition, since better preparations help the individual to successfully enhance the career outcomes. As Chang, Yang and Jiang (2008) state, vocational school can provide students with internship opportunities through class groups or club activities in order to make up for what they lack. SCCT holds that the education-seeking experiences in early years will foster the students' definite interest in thosase areas, and further form their ideas about engaging in certain job in the future. All the studies' perspectives correspond with each other.

There is significant positive correlation between occupation selection and future employment. Therefore, holding positive viewpoints for a certain job, as well as highly selective intention, will lead to more possibility of doing that job in the future. In the previous literature, Yang and Lin (1998) mention that undergraduates nowadays have a sense of uncertainty in seeking a job because they do not develop a definite direction for future work, and the vague school-to-work transition is also one of the factors that make them feel uneasy. This point-of-view supports our research results. That is to say, if a school can define the characteristics of the department when the students are on campus, and provide definite school-to-work transition courses, it is believed that the number of students who engage in catering R\&D work will gradually increase.

\section{Conclusion and Suggestions}

\subsection{Conclusion}

Most participates were females in the fourth grade in university. General university students and technology university students account for $50 \%$ of the total testers, respectively, with most majoring in hospitality management.

There is significantly positive correlation among R\&D competence, school-to-work transition, self-efficacy, outcome expectation, occupation selection and future employment. Also, the confirmative factor analysis results from each construct present that the adaptability of this model is fair. So, the structural equation was followed, showing that all indicators reached the standard, implying that the adaptability is fair as well. The model can also be used to explain the influence of each construct.

From the results, it is observed that R\&D competence has a significant direct effect on self-efficacy, supporting H1. However, its direct effect on outcome expectation is not significant, although the total effect is remarkable, signifying that $\mathrm{R} \& \mathrm{D}$ competence in relation to outcome expectation item is not supportive of H2. As for school-to-work transition's effect on self-efficacy and outcome expectation, it is also remarkable, showing support for $\mathrm{H} 3$ and $\mathrm{H} 4$ in this study. Furthermore, self- efficacy's direct effect on outcome expectation is significant, so it supports H5. Self- efficacy and outcome expectation's direct effect on future employment reached significance, so it supports H8.

\section{Suggestions}

\subsection{Suggestions for Schools}

Our research results on $\mathrm{R} \& \mathrm{D}$ competence indicate that the students today generally identify their personality characteristics as positive attitudes, personality stability, and ability to cope with innovation \& change. However, it is found that the scores on product skills and management ability tend to be low; therefore, courses in school can focus more on understanding the raw materials and students' cost calculation ability. In regard to management ability, schools should provide more courses on foreign languages to make students more competitive globally, together with team 
collaboration models in the courses to enhance their management ability unconsciously. By such methods in an improved teaching environment, it is believed that their general understanding of R\&D work will be greatly enhanced.

From the results of the school-to-work transition, it is clear that students feel uncertain about the school-to-work transition service provided by their school. As a result, it is suggested that schools should conduct employment consultancy and evaluation upon students' entrance into the university, so that they can plan for the future employment in advance, and confirm their goals in the future. Besides, students should be provided with definite and clear employment information, become familiar with their major, and thus develop an overall understanding of the whole industry's advantages and disadvantages. In this respect, we recommend the schools put more emphasis on operations related to the hospitality industry. For instance, schools can offer more lectures, and industry can arrange more industry promotion activities, such as visits and internships. Through assistance and suggestions from the teachers, the students' interest may be better connected with work, by setting up a more complete mentoring mechanism. However, it is worth noting that, in spite of many lectures held by many schools, actual evaluation of those lectures' effect on the students is necessary in order to prevent wasted resources or ineffectiveness for the students. The business units may also offer more encouraging elements so that the students may have more opportunities for diversified development, and to make sound preparations for stepping into the workplace.

Today, education is degree-oriented in general universities, and industry- education cooperation in technology universities. From the research results, it can be seen that the educational direction in technology universities lies in helping enterprises to cultivate elites. Also, the results tell us that technology universities are superior to the general universities, so we suggest that they maintain their conditions, and try to make some improvement. For example, the school can strengthen the pre-work consultancy for internship, hold up some sharing seminars, and make close interaction between the school and the business unit. Regarding schoolwork, schools can make surveys to get an idea of what the students feel insufficient, and then add new materials into the course. Besides, it is suggested that the students consolidate their learning foundation, which will be helpful for their transition to work in the future. As for general universities, it is usually considered that their students perform better than those in technology universities in most disciplines. As proved in this research, their R\&D competence is certainly better, but it is not such case in other respects. Therefore, it is recommended that more creativity-related courses can be added to the existing courses (e.g. R\&D menu), and practice-related content into the theoretical courses. If it is permitted, the school should provide more internship opportunities to correspond to the fast changing employment market.

\subsection{Suggestions for Students}

This research demonstrates that regarding gender in occupation selection, the males surpass the females; we recommend that the students eliminate their prejudices on gender in work so that the subsequent development, absorption and experiences of the course content can remain balanced, and make good preparations for subsequent work. During the university stage, the catering/hospitality-related majoring students should try diversified dimensions to endure whether they are suitable for the catering industry without wasting time on this discipline if they not interested at all. Besides, in university, students enrich their information and knowledge, as well as social contacts. On the other hand, students should develop their linguistic ability. Importantly, a teamwork spirit can be cultivated during this period. In this regard, it is required to establish a moral character and optimistic attitude. Actually, research has proven that holding a positive evaluation on self-efficacy will have a positive impact on future employment. Since selection of courses is mostly decided by oneself, trying to listen and learn more sincerely in knowledge seeking, and trying to experience the sense of achievement from team cooperation will help a lot in catering R\&D work in the future.

It is certain that students should maintain and improve their good performance in school work. In this research, the students considered that they performed poorly in product skills. For this part, students can improve by participating in more catering study lectures held by various universities in daily times, and can even visit new product launches to extract new product information. In extracurricular time, classmates may work together to earn some catering-related certificates, to obtain more guaranteed employment in the future.

After confirming one's interest in catering R\&D work, one is not just restricted to learning related knowledge in class, but should also actively participate in outside activities. The catering-related departments should regularly hold seminars or advanced study courses to provide relevant knowledge. Moreover, the public and private sectors often hold useful lectures on health or creativity, so taking part in more activities like these is helpful for the future as well. In particular, the most insufficient area for the general undergraduates is practice, so making up for this deficiency will certainly have a positive effect on future employment.

\subsection{Suggestions for Enterprises}

An effective approach to recruiting catering $R \& D$ talents is to establish the internship system through industry-education cooperation. If necessary, industries can provide scholarships to attract competent students, maintain 
a good image, receive school personnel in visiting activities, and maintain good interactions with the related departments. We believe they will thereby successfully recruit the required elites. Regarding internal cultivation, they should provide proper training for the employees in collaboration with appropriate courses based on the governmental regulations and statuary.

\subsection{Suggestions for Future Research}

This study conducted a questionnaire survey (in coordination with qualitative research like visits, observation, or case study) and in-depth interviews aiming at items with significant difference, and analyzed the causes to culminate the study and endow it with research value. In addition, due to limitations of time and labor, students in the hospitality-related departments were the subjects. Therefore, the results may not be applicable to other undergraduates in Taiwan. It is thus suggested that future research can refer to other related departments (like food science and nutrition) for comparison to enlarge the deduction range, and thereby achieving a more complete investigation of $R \& D$ competence and school-to-work transition. Due to the large quantity of questionnaires and the limited time frame, the answers may not be sound enough, and may distort the real implications of the questions. Consequently, we also suggest that the future research should consider the quantity of the questions, so that more reliable data may be generated.

\section{References}

Abbey, A., \& Discon, J. W. (1983). R \& D Work Climate and Innovation in Semiconductors. Academy of Management, 26(2), 362-368. https://doi.org/10.2307/255984

Alpern, B. E. (2000). Factors that influence community college transfer students' satisfaction with their baccalaureate institutions. Unpublished doctoral dissertation, University of Michigan-Ann Arbor.

Anderson, J., \& Gerbing, D. (1988). Structural equation modeling in practice: A review and recommended two-step approach. Psychological Bulletin, 103(3), 411-423. https://doi.org/10.1037/0033-2909.103.3.411

Baer, R. M., Daviso, A. W., Flexer, R. W., Queen, R. M., \& Meindl, R. S. (2011). Students with intellectual disabilities: Predictors of transition outcomes. Career Development for Exceptional Individuals, 34, 132-141. https://doi.org/10.1177/0885728811399090

Bagozzi, R., \& Yi, Y. (1988). On the evaluation of structural equation models. Journal of the Academy of Marketing Science, 16(1), 74-94. https://doi.org/10.1007/BF02723327

Berger, J. B., \& Malaney, G. D. (2001). Assessing the transition of transfer students from community college to a university. Journal of Student Affairs Research and Practice, 40(4), 533-555.

Blanco, A. (2011). Applying social cognitive career theory to predict interests and choice goals in statistics among Spanish psychology students. Journal of Vocational Behavior, 78, 49-58. https://doi.org/10.1016/j.jvb.2010.07.003

Brint, S. (2006). Schools and Socialization, in Gerald Handel ed., Childhood socialization (New Brunswick, N.J.: Aldine Transaction), 157-174.

Chang, S. N., Yang, C. H., \& Chiang, C. T. (2008). An analysis of college seniors' self- perceived core employability and their relevant factors: National Ilan university as a case study. The Journal of Liberal Arts and Management, 5(11), 255-302.

Chen, C. P. (2005). Understanding career chance. International Journal of Educational and Vocational Guidance, 5 , 251-270. https://doi.org/10.1007/s10775-005-3600-7

Creed , P. A., \& Hughes, T. (2013). Career development strategies as moderators between career compromise and career outcomes in emerging adults. Journal of Career Development, 40(2), 146-163. https://doi.org/10.1177/0894845312437207

Fornell, C., \& Larcker, D. F. (1981). Evaluating structural equation models with unobservable variables and measurement error. Journal of Marketing Research, 18, 39-50. https://doi.org/10.2307/3151312

Gordon, V. N., \& Habley, W. R. (2000).Academic advising: A comprehensive handbook. San Francisco: Jossey- Bass.

Hartung, P. J., \& Taber, B. J. (2008). Career construction and subjective well-being. Journal of Career Assessment, 16(1), 75. https://doi.org/10.1177/1069072707305772

Hendricks, D. R., \& Wehman, P. (2009). Transition from school to adulthood for youth with autism spectrum disorders. Focus on Autism and Other Developmental Disabilities, 24, 77-88. https://doi.org/10.1177/1088357608329827

Hirschi, A. (2010). The role of chance events in the school-to-work transition: The influence of demographic, personality and career development variables. Journal of Vocational Behavior, 77, 39-49. 
https://doi.org/10.1016/j.jvb.2010.02.002

Hirschi, A., Niles, S. G., \& Akos, P. (2011). Engagement in adolescent career preparation: Social support, personality and the development of choice decidedness and congruence. Journal of Adolescence, 34(1), 173-182. https://doi.org/10.1016/j.adolescence.2009.12.009

Huang, C. S. (2005). The change of food industry from innovation view. Food marketing news, 94(8), 64-65 。

Huang, S. Y., \& Ma, A. H. S. (2011). Turn Left, Turn Right: Understanding the Developmental Trajectory of and Social Influence on Educational and Career Choices through Life History. Review of Social Sciences, 5(1), 139-200.

Johnson, D. R., McGrew, K., Bloomberg, L., Lin, H. C., \& Bruininks, R. H. (1995). Descriptive findings of the National Transition Study of Individuals with Severe Disabilities Leaving School. Minneapolis: University of Minnesota, Institute on Community Integration.

Joreskog, K. G., \& Sorbom, D. (1993). LISREL 8: User's Reference Guide. Scientific Software International. Chicago, I.L.

Kline, R. B. (2005). Principles and practice of structural equation modeling (2nd ed.). New York: The Guilford Press.

Ko, W. H. (2012). The relationships among professional competence, job satisfaction and career development confidence for chefs in Taiwan. International Journal of Hospitality Management, 31, 1004-1011. https://doi.org/10.1016/j.ijhm.2011.12.004

Ko, W. H. (2015). Constructing a professional competence scale for foodservice research \& development employees from an industry viewpoint. International of Journal of Hospitality Management, 49, 66-72. https://doi.org/10.1016/j.ijhm.2015.06.002

Ko, W. H., \& Gu, R. C. (2014). Food service R\&D personnel's professional competence and importance evaluation. 13th Asia Pacific Forum for Graduate Students Research in Tourism, May, 14-16, National Kaohsiung University, Kaohsiung, Taiwan.

Ko, W. H., \& Li, C. C. (2010). The study on relationship among professional competence, continuing education and career Development for Chinese chef in Taiwan. Journal of Hospitality and Home Economics, 7, 261-284.

Koivisto, P., Vinokur, A. D., \& Vuori, J. (2011). Effects of career choice intervention on components of career preparation. The Career Development Quarterly, 59(4), 345-366. https://doi.org/10.1002/j.2161-0045.2011.tb00074.x

Lent, R. W., Brown, S. D. \& Hackett, G., (1994). Toward a unifying social cognitive theory of career and academic interest, choice, and performance. Journal of Vocational Behavior, 45, 79-122. https://doi.org/10.1006/jvbe.1994.1027

Lent, R. W., Hackett, G., \& Brown, S. D. (1999). A social cognitive view of school-to-work transition. Career Development Quarterly, 47, 297-311. https://doi.org/10.1002/j.2161-0045.1999.tb00739.x

Lin, G. H. (2001). The new viewpoint to learn from school- to- work. The Teacher Monthly, 530, 61-65.

McClelland, D. C. (1973). Testing for Competence rather than for Intelligence. American Psychologist, 28(1), 1-24. https://doi.org/10.1037/h0034092

Pryor, R. G. L., \& Bright, J. E. H. (2006). Counseling chaos: Techniques for practitioners. Journal of Employment Counseling, 43, 2-16. https://doi.org/10.1002/j.2161-1920.2006.tb00001.x

Pryor, R. G. L., Amundson, N. E., \& Bright, J. E. H. (2008). Probabilities and possibilities: The strategic counseling implications of the chaos theory of careers. The Career Development Quarterly, 56, 309-318. https://doi.org/10.1002/j.2161-0045.2008.tb00096.x

Rothwell, A., Jewell, S., \& Hardie, M. (2009). Self-perceived employability: investigating the responses of post-graduate students. Journal of Vocational Behavior, 75, 152-161. https://doi.org/10.1016/j.jvb.2009.05.002

Saks, A. M., \& Ashforth, B. E. (2002). Is job search related to employment quality? It all depends on the fit. Journal of Applied Psychology, 87(4), 646-654. https://doi.org/10.1037/0021-9010.87.4.646

Savickas, M. L. (1999). The transition from school to work: A developmental perspective. Career Development Quarterly, 47, 326-336. https://doi.org/10.1002/j.2161-0045.1999.tb00741.x

Scholarios, D., Van der Heijden, B. I. J. M., Van der Schoot, E., Bozionelos, N., Epitropaki, O., \& Jedrzejowicz, P. (2008). Employability and the psychological contract in European ICT sector SMEs. International Journal of Human Resource Management, 19(6), 1035-1055. https://doi.org/10.1080/09585190802051337 
Sethi, V., \& King, W. R. (1994). Development of measurement to assess the extent to which an information technology application provides competitive advantage. Management Science, 40, 1601-1624. https://doi.org/10.1287/mnsc.40.12.1601

Spencer, L. M., \& Spencer, S. M. (1993). Competence at work- models for superior performance. NY: John Wiley \& Sons.

Stringer, K., Kerpelman, J. L., \& Skorikov, V. B. (2011). Career preparation: A longitudinal, process-oriented examination. Journal of Vocational Behavior, 79, 158-169 . https://doi.org/10.1016/j.jvb.2010.12.012

Swanson, J. L., \& Tokar, D. M. (1991). Development and initial validation of the career barriers inventory. Journal of Vocational Behavior, 39, 344-361. https://doi.org/10.1016/0001-8791(91)90043-L

Wang, L. L., \& Shi, H. P. (2005). The study of the relationship between career self-efficacy and career barriers of undergraduates in the department of hotel and restaurant management. Journal of Hospitality and Home Economics, 2(1), 33-50.

Will, M. C. (1984). OSERS Programming for the Transition of Youth with Disabilities: Bridges from School to Working Life. Washington, DC: Office of Special Education and Rehabilitative Services (OSERS), U. S. Department of Education.

Yang, C. S., \& Lin, S. H. (1998). A study on the relationship between career development and ego identity status for college students in Taiwan. Bulletin of Educational Psychology, 30(2), 1-16.

Yu, M. N., Chao, P. C., \& Chen, C. C. (2010). Investigating the factors on mathematics career- choice intentions with the social cognitive career theory. Journal of Research in Education Sciences, 55(3), 177-201.

\section{Copyrights}

Copyright for this article is retained by the author(s), with first publication rights granted to the journal.

This is an open-access article distributed under the terms and conditions of the Creative Commons Attribution license which permits unrestricted use, distribution, and reproduction in any medium, provided the original work is properly cited. 